Original article

DOI: https://doi.org/10.21285/2227-2925-2021-11-4-531-539

\title{
Synthesis and crystal structure of cytotoxic copper(II) complex with 1,10-phenanthroline-5,6-dione and isothiazole derivative
}

\author{
Yuliya A. Golubeva*, Ksenia S. Smirnova*, Lubov’ S. Klyushova**, \\ Vladimir I. Potkin ${ }^{\star \star \star}$, Elizaveta V. Lider \\ *Nikolaev Institute of Inorganic Chemistry, SB RAS, \\ Novosibirsk, Russian Federation \\ ${ }^{* *}$ Institute of Molecular Biology and Biophysics, Federal Research Center foe Fundamental \\ and Translational Medicine, Novosibirsk, Russian Federation \\ ***Institute of Physical Organic Chemistry of the National Academy of Sciences of Belarus, \\ Minsk, Belarus \\ Corresponding author: Elizaveta V. Lider, lisalider@ngs.ru
}

\begin{abstract}
Oligopyridine based copper(II) complexes are of interest to scientists as possible anticancer agents due to promising cytotoxic and DNA binding/cleaving properties. In this study, copper(II) complex $\left[\mathrm{Cu}\right.$ (phendione) $\left.\mathrm{L}_{2}\right] \cdot \mathrm{C}_{2} \mathrm{H}_{5} \mathrm{OH}$ with 1,10-phenanthroline-5,6-dione (phendione) and 4,5-dichloro-isothiazole-3carboxylic acid (HL) was synthesized and characterized by elemental analysis, IR-spectroscopy, X-ray powder diffraction and single-crystal $X$-ray diffraction. According to $X$-ray diffraction data, obtained compound is mononuclear complex with square pyramidal coordination environment of the central atom which is surrounded by two isothiazolate molecules and one phendione ligand. The $X$-ray diffraction data are confirmed by IR-spectroscopy data showing the presence of characteristic stretching vibration bands of the carbonyl and carboxyl groups of oligopyridine ligand and isothiazolate ions, respectively. Density functional theory (DFT) calculations for complex were carried out using the ADF software package to perform geometry optimization and frequency calculations that were in a good agreement with experimental IR spectrum. Cytotoxicity of complex and initial reagents was tested in vitro against HepG2 (human hepatocellular carcinoma) and MCF-7 (human breast adenocarcinoma) cell lines. The complex showed high dose-dependent cytotoxic activity with the $I C_{50}$ values of $0.60 \pm 0.03 \mu \mathrm{M}$ and $0.96 \pm 0.13 \mu \mathrm{M}$, respectively, which is higher than the activity of cisplatin against these cell lines. The activity of the complex is due to the presence of phendione ligand, which exhibits a similar cytotoxic activity.
\end{abstract}

Key words: copper complex, isothiazole, crystal structure, phenanthroline, cytotoxicity

Acknowledgments. The authors thank A. P. Zubareva and N. N. Komardina for the elemental analysis, A. O. Matveeva for the X-ray phase analysis data, T. S. Sukhikh for providing the data collected in XRD Facility of NIIC SB RAS. The work was performed using the equipment of the Center for Collective Use "Proteomic Analysis", supported by funding from the Ministry of Science and Higher Education of the Russian Federation (agreement no. 075-15-2021-691).

Funding. The reported study was funded by RFBR (project no. 20-33-90092).

The research (Nikolaev Institute of Inorganic Chemistry SB RAS) was supported by the Ministry of Science and Higher Education of the Russian Federation (no. 121031700321-3).

For citation: Golubeva Yu. A., Smirnova K. S., Klyushova L. S., Potkin V. I., Lider E. V. Synthesis and crystal structure of cytotoxic copper(II) complex with 1,10-phenanthroline-5,6-dione and isothiazole derivative. Izvestiya Vuzov. Prikladnaya Khimiya $i$ Biotekhnologiya $=$ Proceedings of Universities. Applied Chemistry and Biotechnology. 2021;11(4):531-539. (In English). https://doi.org/10.21285/2227-2925-2021-11-4-531-539.

(c) Golubeva Yu. A., Smirnova K. S., Klyushova L. S., Potkin V. I., Lider E. V., 2021 
Golubeva Yu. A., Smirnova K. S., Klyushova L. S. et al. Synthesis and crystal structure ...

Голубева Ю. А., Смирнова К. С., Клюшова Л. С. и др. Синтез и кристаллическая структура ...

Научная статья

УДК 54.057;546.562;615.277.3

\title{
Синтез и кристаллическая структура цитотоксического комплекса меди(II) с 1,10-фенантролин-5,6-дионом и производным изотиазола
}

\author{
Юлия Андреевна Голубева*, Ксения Сергеевна Смирнова *, \\ Любовь Сергеевна Клюшова **, Владимир Иванович Поткин ***, \\ Елизавета Викторовна Лидер *
}

\author{
*Институт неорганической химии им. А. В. Николаева СО РАН, \\ 2. Новосибирск, Российская Федерация \\ **Научно-исследовательский институт молекулярной биологии и биофизики - структурное \\ подразделение Федерального исследовательского центра фрундаментальной \\ и трансляционной медицины, г. Новосибирск, Российская Федерация \\ **^Институт физико-органической химии Национальной академии наук Беларуси, \\ 2. Минск, Беларусь
}

Автор, ответственный за переписку: Лидер Елизавета Викторовна, lisalider@ngs.ru

\begin{abstract}
Аннотация. Комплексы меди(II) на основе олигопиридинов привлекают интерес исследователей в качестве возможных противоопухолевых агентов ввиду их выдающихся цитотоксических свойств и способности связываться/расщеплять ДНК. В настоящем исследовании был получен и охарактеризован с помощью ИК-спектроскопии, элементного, рентгенофразового и рентгеноструктурного анализа комплекс меди(II) с 1,10-френантролин-5,6-дионом (phendione) и 4,5-дихлоро-изотиазол-З-карбоновой кислотой, [Cu(phendione) $\left.L_{2}\right] \cdot C_{2} H_{5} \mathrm{OH}$. Согласно данным рентгеноструктурного анализа, полученное соединение является моноядерным, при этом две молекулы изотиазола и 1,10-френантролин-5,6-дион образуют квадратно-пирамидальное окружение центрального атома. Данные рентгеноструктурного анализа согласуются с данными ИК-спектроскопии, указывающими на наличие характеристичных полос валентных колебаний карбонильной и карбоксильной групп олигопиридина и производного изотиазола соответственно. Расчеты, выполненные методом теории функционала плотности (DFT) с использованием программного пакета ADF, позволили оптимизировать геометрию комплекса и вычислить теоретический ИК-спектр, который хорошо согласуется с экспериментальным. Цитотоксичность комплексов и исходных реагентов исследована на клеточных линиях НерG2 (гепатоцеллюлярная карцинома) и MCF-7 (аденокарцинома молочной железы). Комплекс проявляет высокую дозозависимую цитотоксическую активность, при

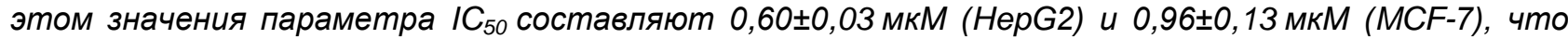
превышает активность цисплатина по отношению к данным клеточным линиям. Активность комплекса обусловлена присутствием лиганда phendione, который в свободном виде также обладает токсичностью.
\end{abstract}

Ключевые слова: комплекс меди, изотиазол, кристаллическая структура, френантролин, цитотоксичнсоть

Благодарности. Авторы выражают благодарность А. П. Зубаревой и Н. Н. Комардиной за предоставление данных элементного анализа, А. О. Матвеевой - за предоставление данных рентгенофазового анализа, Т. С. Сухих - за предоставление данных, измеренных в рентгенодифракционном ЦКП ИНХ СО РАН.

Финансирование. Исследование выполнено при финансовой поддержке РФФИ в рамках научного проекта № 20-33-90092.

Работа выполнена с использованием оборудования ЦКП «Протеомный анализ», поддержанного фринансированием Минобрнауки России (соглашение № 075-15-2021-691).

Для цитирования: Голубева Ю. А., Смирнова К. С., Клюшова Л. С., Поткин В. И., Лидер Е. В. Синтез и кристаллическая структура цитотоксического комплекса меди(II) с 1,10-френантролин-5,6-дионом и производным изотиазола // Известия вузов. Прикладная химия и биотехнология. 2021. Т. 11. N 4. С. 531-539. https://doi.org/10.21285/2227-2925-2021-11-4-531-539. 
Golubeva Yu. A., Smirnova K. S., Klyushova L. S. et al. Synthesis and crystal structure ... Голубева Ю. А., Смирнова К. С., Клюшова Л. С. и др. Синтез и кристаллическая структура ...

\section{INTRODUCTION}

Currently, mixed-ligand complexes of essential metals with 1,10-phenanthroline and its derivatives are being actively studied in vitro and in vivo for their biological properties (cytotoxic, antioxidant, antibacterial, antiviral and other activities) [1-7]. Essential metals include such microelemets as iron, copper, zinc, cobalt, nickel, manganese and some other metals. Among the complexes of essential metals, the most interesting as anticancer agents are 1,10-phenanthroline based copper(II) complexes, since they are capable to interact and cleave DNA/RNA backbone $[8,9]$. Moreover, oligopyridine and amino acid/acetylacetone based copper(II) complexes (Casiopeínas) have shown antiproliferative, genotoxic, and antineoplastic activity [10,11]. The most promising complexes from the Casiopeinas series have completed preclinical trials [12]. Besides amino acids, $\mathrm{N}$-donor systems (terpyridine, imidazole, benzimidazole, tetrazole), O-donor systems (salicylic acid, dicarboxylic acids), S-donor systems (thiosemicarbazones, dithiocarbamates, thioureas), Schiff bases are often used as secondary ligand in synthesis of cytotoxic Casiopeinas-like complexes [6]. The isothiazole heterocycles and coordination compounds with isothiazoles have been shown to be bioactive substances with pesticidal, anticancer, anti-inflammatory and antiviral activities [13]. However, despite their promising properties, isothiazoles are negligibly used for the synthesis of bioactive oligopyridine based complexes with essential metals. Thus, the research aiming preparation of corresponding complexes may be indeed promising from the point of view of medicinal chemistry.

In continuation of our work [14] in order to expand the number of available cytotoxic oligopyridine based complexes with isothiazole as secondary ligand, the present study set out to synthesise new mixed-ligand copper(II) complex with 1,10-phenanthroline-5,6-dione and 4,5-dichloro-isothiazole-3carboxylic acid and evaluate its biological activity.

\section{EXPERIMENTAL SECTION}

1,10-Phenanthroline-5,6-dione (phendione) was acquired from ABCR (Germany). 4,5-Dichloro-isothiazole-3-carboxylic acid (HL) was synthesized as previously described $[15,16]$. Solvents and reagents were used as purchased without any further purification.

Elemental analysis $(\mathrm{C}, \mathrm{H}, \mathrm{N})$ was performed using Euro EA 3000 analyzer. IR absorption spectra were recorded on SCIMITAR FTS 2000 and VERTEX-80 spectrophotometers at $4000-400 \mathrm{~cm}^{-1}$ (in fluorinated oil - in the region of $4000-1500 \mathrm{~cm}^{-1}$, in vaseline oil - 1800-400 $\mathrm{cm}^{-1}$ ). Powder XRD analysis of complexes was performed on a Shimadzu XRD-7000 diffractometer (CuKa radiation, Ni filter, $3-40^{\circ} 2 \theta$ range, $0.03^{\circ} 2 \theta$ step, room temperature).
Quantum-chemical calculations were carried out on the computational cluster of NIIC SB RAS using the Amsterdam Density Functional (ADF) program by dint of density functional theory (DFT) ${ }^{1}$. The generalized gradient approximation (GGA), the density functional PBE (Perdew - Burke - Ernzerhof) [17] in combination with the all electron basis set TZ2P [18] were applied. The calculations were carried out for non-solvent system.

Bruker D8 Venture diffractometer with the graphite-monochromated $\mathrm{MoK}_{\alpha}$ radiation $(\lambda=0.71073 \AA)$ was utilized to collect single-crystal XRD data for copper(II) complex. All measurements were carried out at $150 \mathrm{~K}$, and the $\varphi$ - and $\omega$-scan techniques were employed. Absorption corrections were applied with the SADABS program ${ }^{2}$. The crystal structure was solved and refined by means of the SHELXT [19] and SHELXL [20] programs using OLEX2 GUI [21]. Atomic thermal displacement parameters for non-hydrogen atoms were refined anisotropically. Positions of hydrogen atoms were calculated according to their geometrical conditions and refined by dint of the riding model. The crystallographic data and details of the structure refinements are shown in Table 1. CCDC 2121029 contains the supplementary crystallographic data for this paper. These information can be obtained free of charge from The Cambridge Crystallographic Data Center at https://www.ccdc.cam.ac.uk/structures/.

Synthesis of [Cu(phendione) $\left.\mathrm{L}_{2}\right] \cdot \mathrm{C}_{2} \mathrm{H}_{5} \mathrm{OH}$. $\left[\mathrm{Cu}\left(\mathrm{H}_{2} \mathrm{O}\right) \mathrm{L}_{2}\right]$ was synthesized as previously described [14]. The precipitate of $\left[\mathrm{Cu}\left(\mathrm{H}_{2} \mathrm{O}\right) \mathrm{L}_{2}\right](0.048 \mathrm{~g}, 0.10 \mathrm{mmol})$ was resuspended in mixture of ethanol $(2 \mathrm{ml})$ and dichloromethane $(3 \mathrm{ml})$. Solid phendione $(0.025 \mathrm{~g}$, $0.12 \mathrm{mmol}$ ) was added to suspension with stirring. The reaction mixture became clear, precipitate dissolved. The solution was left for slow evaporation at room temperature. Polycrystalline phase was obtained after a week. Green crystals were filtered out, washed with ethanol and dried in air. Yield: $0.064 \mathrm{~g} \mathrm{(90 \% ).} \mathrm{Elemental} \mathrm{analysis} \mathrm{( \% ):} \mathrm{Calc.} \mathrm{for}$ $\mathrm{C}_{22} \mathrm{H}_{12} \mathrm{Cl}_{4} \mathrm{CuN}_{4} \mathrm{O}_{7} \mathrm{~S}_{2}$ : C, 37.0; $\mathrm{H}, 1.7 ; \mathrm{N}, 7.8$. Found: C, 37.3; H, 1.8; N, 7.7.

Cytotoxic activity. Human hepatocellular carcinoma (HepG2) and human breast adenocarcinoma (MCF-7) cell lines were cultured in Iscove's Modified Dulbecco's Medium (IMDM) supplemented with a $10 \%$ fetal bovine serum under a humidified atmosphere $\left(5 \% \mathrm{CO}_{2}\right.$ and $95 \%$ air) at $37^{\circ} \mathrm{C}$. Cell viability was evaluated by Hoechst/PI staining as previously described [22]. Hep2 cells were cultured to 96-well plates at a density $5 \cdot 10^{3}$ cells per well. After 24 hours cells were treated with complex dissolved in DMSO and incubated for 48 hours. Serial dilutions were prepared in IMDM medium in the concentration range of $0.1-25 \mu \mathrm{M}$. For identification of live, apoptotic and dead cells, treated cells and control cells were stained with a mixture of fluorescent dyes

\footnotetext{
${ }^{1}$ ADF2013, Software for Chemistry \& Materials, Theoretical Chemistry, Vrije Universiteit, Amsterdam (The Netherlands), 2013.

${ }^{2}$ Bruker Apex3 software suite: Apex3, SADABS-2016/2 and SAINT, version 2018.7-2; Bruker AXS Inc.: Madison, WI, 2017.
} 
Golubeva Yu. A., Smirnova K. S., Klyushova L. S. et al. Synthesis and crystal structure ...

Голубева Ю. А., Смирнова К. С., Клюшова Л. С. и др. Синтез и кристаллическая структура ...

Hoechst 33342 (Sigma-Aldrich) and propidium iodide (Invitrogen) for $30 \mathrm{~min}$ at $37^{\circ} \mathrm{C}$. An IN Cell Analyzer 2200 (GE Healthcare, UK) was used to perform automatic imaging of four fields per well under 200×magnification, in bright field and fluorescence channels. The IN Cell Investigator image analysis software (GE Healthcare, UK) was used to determine live, apoptotic and dead cells among the whole population. All data shown are mean of three wells. The quantitative data were expressed as the mean \pm standard deviation (SD). All statistical analyses were performed using the software Excel 2016 (Microsoft) and Origin 8.0.

Table 1. Crystallographic data of the copper(II) complex

Таблица 1. Кристаллографические данные для комплекса меди(II))

\begin{tabular}{|c|c|}
\hline Parameter & Value \\
\hline Empirical formula & $\mathrm{C}_{22} \mathrm{H}_{12} \mathrm{Cl}_{4} \mathrm{~N}_{4} \mathrm{O}_{7} \mathrm{~S}_{2} \mathrm{Cu}$ \\
\hline Formula weight & 713.82 \\
\hline $\begin{array}{l}\text { Crystal system, } \\
\text { space group }\end{array}$ & Monoclinic, P21/c \\
\hline Temperature $(\mathrm{K})$ & 150 \\
\hline$a / \AA$ & $11.2744(15)$ \\
\hline $\mathrm{b} / \AA$ & $8.5017(11)$ \\
\hline$c / \AA ̊$ & $28.481(3)$ \\
\hline$\alpha /^{\circ}$ & 90 \\
\hline$\beta /^{\circ}$ & $94.024(5)$ \\
\hline$\gamma /^{\circ}$ & 90 \\
\hline Volume $/ \AA^{3}$ & $2723.2(6)$ \\
\hline Z & 4 \\
\hline$\rho_{\text {calc }} \mathrm{g} / \mathrm{cm}^{3}$ & 1.741 \\
\hline$\mu / \mathrm{mm}^{-1}$ & 1.399 \\
\hline Crystal size $/ \mathrm{mm}$ & $0.3 \times 0.2 \times 0.12$ \\
\hline $\begin{array}{l}2 \Theta \text { range } \\
\text { for data collection }{ }^{\circ}\end{array}$ & 4.774 to 51.486 \\
\hline Index ranges & $\begin{array}{c}-13 \leq h \leq 7,-10 \leq k \leq 10 \\
-33 \leq l \leq 34\end{array}$ \\
\hline Reflections collected & 34013 \\
\hline Independent reflections & $\begin{array}{c}5030\left[R_{\text {int }}=0.0520,\right. \\
\left.R_{\text {sigma }}=0.0398\right]\end{array}$ \\
\hline Restraints/parameters & $0 / 363$ \\
\hline Goodness-of-fit on $F^{2}$ & 1.088 \\
\hline Final $R$ indexes $[l>=2 \sigma(I)]$ & $\mathrm{R}_{1}=0.0423, \mathrm{wR}_{2}=0.0921$ \\
\hline Final $R$ indexes [all data] & $\mathrm{R}_{1}=0.0554, \mathrm{wR}_{2}=0.0971$ \\
\hline $\begin{array}{l}\text { Largest diff. } \\
\text { peak/hole / e/ } \AA^{-3}\end{array}$ & $0.75 /-0.41$ \\
\hline
\end{tabular}

\section{RESULTS AND DISCUSSION}

Green crystals of copper(II) complex $\left[\mathrm{Cu}\right.$ (phendione) $\left.\mathrm{L}_{2}\right] \cdot \mathrm{C}_{2} \mathrm{H}_{5} \mathrm{OH}$ were obtained after slow evaporation of ethanol/dichloromethane (1:1.5 by volume) solution containing $\left[\mathrm{Cu}\left(\mathrm{H}_{2} \mathrm{O}\right) \mathrm{L}_{2}\right]$ and phendione ligand in 1:1.2 molar ratio. Obtained complex is soluble in DMSO, $\mathrm{CH}_{3} \mathrm{CN}$, sparingly soluble in ethanol, $\mathrm{CH}_{2} \mathrm{Cl}_{2}$ and practically insoluble in water. The elemental analysis results for $\left[\mathrm{Cu}\right.$ (phendione) $\left.\mathrm{L}_{2}\right] \cdot \mathrm{C}_{2} \mathrm{H}_{5} \mathrm{OH}$ are consistent with the proposed formula of the complex. The presence of solvent ethanol molecule was confirmed by IR-spectroscopy $\left(\mathrm{v}(\mathrm{OH})=3464,3308 \mathrm{~cm}^{-1}\right)$. Powder X-ray diffraction analysis have been used to demonstrate the identity of single crystal and the synthesized polycrystalline phase of complex which proved the phase purity of the bulk sample (Fig. 1).

According to single-crystal $\mathrm{X}$-ray diffraction data, the copper(II) complex [Cu(phendione) $\left.\mathrm{L}_{2}\right] \cdot \mathrm{C}_{2} \mathrm{H}_{5} \mathrm{OH}$ reveals square pyramidal coordination environment of central atom. The coordination sphere of $\mathrm{Cu}$ (II) consists of two $\mathrm{O}$ atoms of the isothiazoles carboxylates, one $\mathrm{N}$ of the isothiazole ligand and two $\mathrm{N}$ atoms of the phendione (Fig. 2). Additional contact (of $2.772 \AA$ ) is observed between the copper(II) and the $\mathrm{O}$ atom of the isothiazole moiety giving distorted octahedral $5+1$ environment. Also there is outer-sphere ethanol molecule. Similar structure has been observed in our previous work, where bipicoline has been used instead of phendione [14].

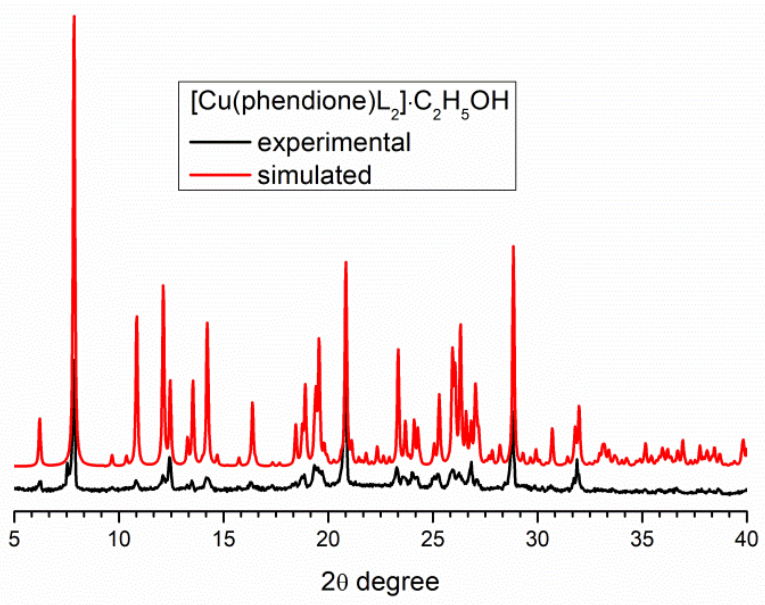

Fig. 1. X-ray powder patterns for [Cu(phendione) $\left.\mathrm{L}_{2}\right] \cdot \mathrm{C}_{2} \mathrm{H}_{5} \mathrm{OH}$ Рис. 1. Дифрактограмма для [Cu(phendione) $\left.\left.\mathrm{L}_{2}\right] \cdot \mathrm{C}_{2} \mathrm{H}_{5} \mathrm{OH}\right)$

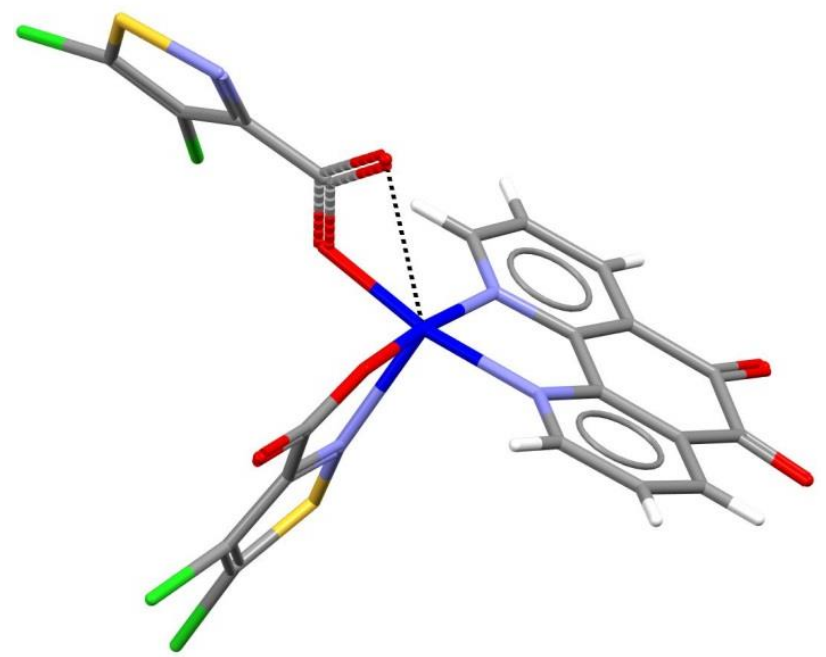

Fig. 2. Structure of $\left[\mathrm{Cu}(\right.$ phendione $\left.) \mathrm{L}_{2}\right]$ complex (Solvent ethanol molecule is not shown)

Рис. 2. Структура комплекса [Cu(phendione) $\left.\mathrm{L}_{2}\right]$ (молекула растворителя не показана)

DFT-calculations, such as IR-frequencies and energies of HOMO/LUMO, have been carried out for copper(II) complex. The highest occupied molecular orbital (HOMO) and lowest-lying unoccupied molecular orbital (LUMO) are known to be the most im- 
Golubeva Yu. A., Smirnova K. S., Klyushova L. S. et al. Synthesis and crystal structure ...

Голубева Ю. А., Смирнова К. С., Клюшова Л. С. и др. Синтез и кристаллическая структура ...

portant orbitals in a molecule. In case of copper(II) complex, the electron density of HOMO (Fig. 3) is concentrated on phendione mainly and energy of this orbital is equal to $-5.978 \mathrm{eV}$. LUMO $(-4,997 \mathrm{eV})$ is disposed on copper ion and donor atoms of its coordination sphere. The energy gap between HOMO and LUMO ( $E_{\text {HOMO }}-E_{\text {LUMO }}$ ) is $-0.981 \mathrm{eV}$. A molecule with large HOMO-LUMO gap is described as a hard molecule which is much less polarizable. In contrast, the soft systems have small HOMOLUMO gap and are highly polarizable [23]. Thus, complex refers to soft molecules due to the small value of energy gap.

Vibrational spectrum has been calculated for the complex with optimized geometry. There are no imaginary frequencies in the obtained spectrum, consequently, the geometry corresponds to local minima. The main vibrational frequencies of calculated and experimental spectra are shown in Table 2. The vibrations of characteristic groups (COO-, $\mathrm{C}-\mathrm{H}$, $\mathrm{C}-\mathrm{Cl}, \mathrm{O}=\mathrm{C}-\mathrm{C}=\mathrm{O}$ ) exhibit in both spectra. The slight shift and broadening of bands is observed in experimental IR-spectrum, which can be due to the presence of ethanol molecule in system. Despite these small differences spectra are in a good agreement.
The obtained IR-spectrum clearly indicates the formation of copper(II) complex. There is a disappearing of broad $\mathrm{v}(\mathrm{O}-\mathrm{H})$ band observed in the $\mathrm{HL}$ spectrum $\left(2915 \mathrm{~cm}^{-1}\right)$ in the result of ligand deprotonation during the synthesis. Moreover, the bands of asymmetrical stretching vibrations of the carboxylate group shift to the low-frequency region $\left(1651-1614 \mathrm{~cm}^{-1}\right)$ in contrast to the band in $\mathrm{HL}$ spectrum $\left(\mathrm{v}(\mathrm{COO})_{\mathrm{as}}=1724 \mathrm{~cm}^{-1}\right)$.

The cytotoxicity of copper(II) complex was tested by Hoechst/PI staining on HepG2 (human hepatocellular carcinoma) and MCF-7 (human breast adenocarcinoma) cell lines by exposing them for $48 \mathrm{~h}$ to the medium containing the compound in $0.1-25 \mu \mathrm{M}$ concentration. The concentration-dependent cell viability graphs are given in Fig. 4. Calculated from these graphs $I_{50}$ values (concentration required to reduce survival in the cell lines to $50 \%$ ) are summarized in Table 3.

Earlier, copper acetate and $\mathrm{HL}$ were shown to be nontoxic in the concentration range of $1-50 \mu \mathrm{M}$ [14]. At the same time, 1,10-phenanthroline-5,6dione is highly toxic to HepG2 and MCF-7 cells with $\mathrm{IC}_{50}$ values being in the nanomolar concentration range [24].

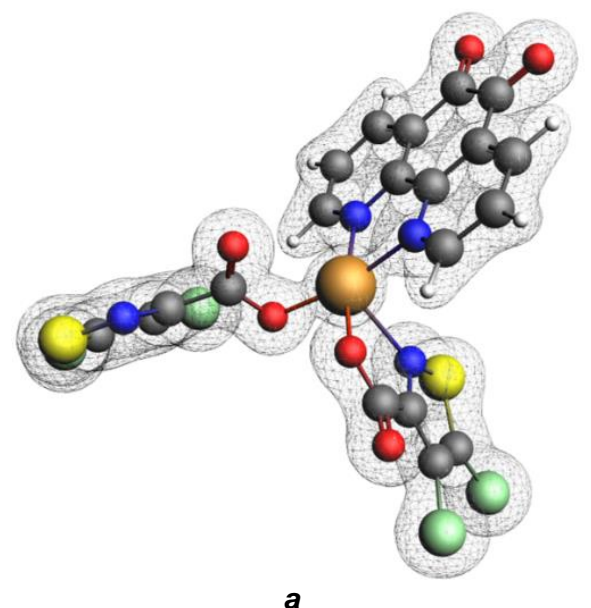

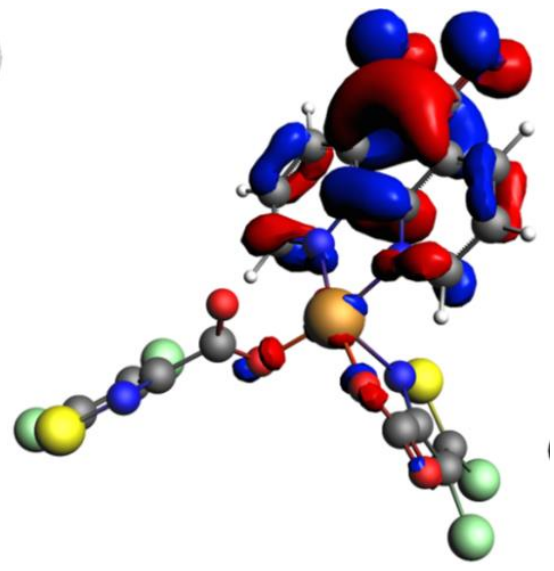

b

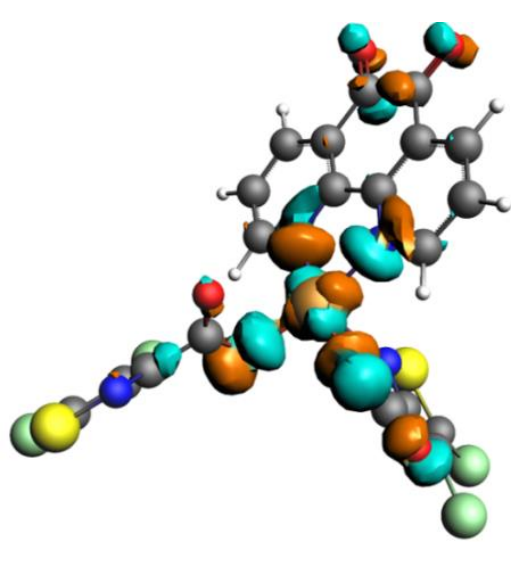

$c$

Fig. 3. Electron density of [Cu(phendione) $\left.\mathrm{L}_{2}\right](\mathrm{a}), \mathrm{HOMO}$ (b) and LUMO (c)

Рис. 3. Электронная плотность [Cu(phendione) $\left.\mathrm{L}_{2}\right](\mathrm{a}), \mathrm{B} 3 \mathrm{MO}$ (b) и $\mathrm{HCMO}$ (c)

Table 2. Calculated and experimental vibrational frequencies $\left(\mathrm{cm}^{-1}\right)$

of $\left[\mathrm{Cu}\right.$ (phendione) $\left.\mathrm{L}_{2}\right]$

Таблица 2. Теоретически рассчитанные и экспериментальные колебательные частоты (см $\left.{ }^{-1}\right)$ комплекса [Cu(phendione) $\mathrm{L}_{2}$ ]

\begin{tabular}{|l|c|c|}
\hline \multicolumn{1}{|c|}{ Assignment, $\mathrm{cm}^{-1}$} & DFT-calculation & Experimental data \\
\hline$v(\mathrm{O}-\mathrm{H})_{\text {EtOH }}$ & - & 3464,3308 \\
$v(\mathrm{C}-\mathrm{H})$ & $3130,3115,3106$ & $3101,3086,3061$ \\
$v(\mathrm{C}-\mathrm{H})_{\text {EtOH }}$ & - & $2960,2924,2856$ \\
$v(\mathrm{O}=\mathrm{C}-\mathrm{C}=\mathrm{O})_{\text {as }}$ & 1692 & 1726 \\
$v(\mathrm{O}=\mathrm{C}-\mathrm{C}=\mathrm{O})_{\mathrm{s}}$ & 1664 & 1710 \\
$v(\mathrm{COO})_{\mathrm{s}}$ & 1642,1628 & 1651,1614 \\
$v(\mathrm{COO})_{\mathrm{s}}$ & 1261 & 1261 \\
$v(\mathrm{C}-\mathrm{Cl})$ & 1055,1044 & 1049,1024 \\
$\mathrm{R}_{\text {rings }}, \delta(\mathrm{C}-\mathrm{H})$ & $1578,1560,1412,1306,1195,1114,979,942$ & $1576,1408,1300,1205,1128,972$ \\
\hline
\end{tabular}


Golubeva Yu. A., Smirnova K. S., Klyushova L. S. et al. Synthesis and crystal structure ...

Голубева Ю. А., Смирнова К. С., Клюшова Л. С. и др. Синтез и кристаллическая структура ...

\section{HepG2 cell line}

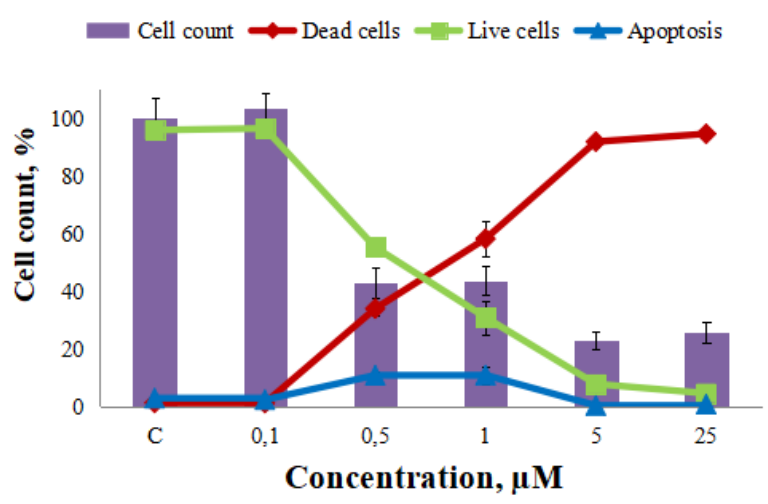

MCF-7 cell line

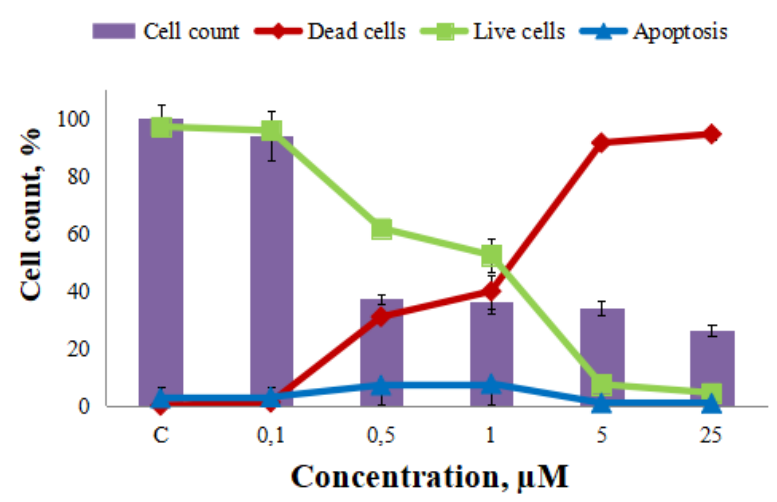

Fig. 4. Effect of $\left[\mathrm{Cu}\right.$ (phendione) $\left.\mathrm{L}_{2}\right] \cdot \mathrm{C}_{2} \mathrm{H}_{5} \mathrm{OH}$ on the viability of $\mathrm{HepG} 2$ and MCF-7 cells

Pис. 4. Эфрфект воздействия [Cu(phendione) $\left.\mathrm{L}_{2}\right] \cdot \mathrm{C}_{2} \mathrm{H}_{5} \mathrm{OH}$ на выживаемость клеток НерG2 и MCF-7

According to cytotoxicity study of [Cu(phendione) $\left.\mathrm{L}_{2}\right] \cdot \mathrm{C}_{2} \mathrm{H}_{5} \mathrm{OH}$, complex possesses dose-depen-dent cytotoxicity against both cell lines $\left(\mathrm{IC}_{50}=0.96 \pm 0.13 \mu \mathrm{M}\right.$ (MCF-7), $0.60 \pm 0.03 \mu \mathrm{M}$ (HepG2)), while its toxicity is higher than that of oligopyridine on HepG2 cells and vice versa on MCF-7 cells (See Table 3 ). Thus, the activity of the complex is due to the presence of phendione ligand, which exhibits a similar cytotoxic activity. The activity of the obtained complex exceeds the activity of cisplatin by more than an order of magnitude.

This compound is part of a series of mixed-ligand copper(II) complexes with $\mathrm{HL}$ and various oligopyridines, and turned out to be the most toxic in this series. So, for example, the $\mathrm{IC}_{50}$ value against MCF-7 cells in the same conditions is $1.8 \pm 0.3 \mu \mathrm{M}$ for $[\mathrm{Cu}(4,7$ dimethyl-1,10-phenanthroline) $\left.\mathrm{L}_{2}\right]$ and $4.2 \pm 0.2 \mu \mathrm{M}$ for [Cu(1,10-phenanthroline) $\left.\left(\mathrm{H}_{2} \mathrm{O}\right) \mathrm{L}_{2}\right]$ [14].

Table 3. $\mathrm{IC}_{50}$ values of the compounds against MCF-7 and HepG2 cell lines

Таблица 3. Значения $\mathrm{IC}_{50}$ для полученных соединений по отношению к клеточным линиям MCF-7 и HepG2

\begin{tabular}{|l|c|c|}
\hline \multicolumn{1}{|c|}{ Compound } & \multicolumn{2}{|c|}{$\mathrm{IC}_{50}$ value, $\mu \mathrm{M}$} \\
\cline { 2 - 3 } & MCF-7 cells & HepG2 cells \\
\hline $\mathrm{Cu}(\mathrm{OAC})_{2}$ & $>50$ & $>50$ \\
$\mathrm{HL}$ & $>50$ & $3.3 \pm 0.6$ \\
1,10 -phenanthroline-5,6-dione & $0.73 \pm 0.06$ & $0.60 \pm 0.03$ \\
{$\left[\mathrm{Cu}\right.$ (phendione) $\left.\mathrm{L}_{2}\right] \cdot \mathrm{C}_{2} \mathrm{H}_{5} \mathrm{OH}$} & $0.96 \pm 0.13$ & $33.0 \pm 5.4$ \\
Cisplatin & $33.7 \pm 1.8$ & \\
\hline
\end{tabular}

\section{CONCLUSIONS}

Mononuclear copper(II) complex based on 4,5-dichloro-isothiazole-3-carboxylic acid and 1,10-phenanthroline-5,6-dione [Cu(phendione) $\mathrm{L}_{2}$ ] has been obtained and characterized by several physicochemical methods. The results of single crystal X-ray diffraction indicate that complex reveals square pyramidal coordination environment of central atom which consist of two $\mathrm{O}$ atoms of the isothiazoles carboxylates, one $\mathrm{N}$ of the isothiazole ligand and two $\mathrm{N}$ atoms of the phendione. According to DFT-calculations, the value of energy gap between HOMO and LUMO of complex is small $(-0.981 \mathrm{eV})$, thus, $\left[\mathrm{Cu}(\right.$ phendione $\left.) \mathrm{L}_{2}\right]$ refers to soft molecules. This compound causes pronounced cytotoxic effect against HepG2 and MCF-7 cells in 0.1-25 concentration range which is an order of magnitude higher than cisplatin cytotoxicity. $\left[\mathrm{Cu}\right.$ (phendione) $\left.\mathrm{L}_{2}\right]$ is part of a series of mixed-ligand copper(II) complexes with $\mathrm{HL}$ and various oligopyridines. Cytotoxicity of these complexes increases with the transition from 1,10-phenanthroline to 4,7-dimethyl-1,10-phenanthroline and is maximal in the 1,10-phenanthroline-5,6-dione based complex. Thus, this work helps to understand structure-cytotoxic activity relationships for the oligopy-ridine based isothiazole copper(II) complexes.

\section{REFERENCES}

1. Bencini A., Lippolis V. 1 ,10-Phenanthroline: $A$ versatile building block for the construction of ligands for various purposes. Coordination Chemistry Reviews. 2010;254(17):2096-2180. https://doi. org/10.1016/j.ccr.2010.04.008.

2. Krasnovskaya O., Naumov A., Guk D., Gorelkin P., Erofeev A., Beloglazkina E., et al. Copper coordination compounds as biologically active agents.
International Journal of Molecular Sciences. 2020;21(11): 3965. https://doi.org/10.3390/ijms21113965.

3. Dey D., Roy A. B., Ranjani A., Gayathri L., Chandraleka S., Dhanasekaran D., et al. Synthesis and bio-catalytic activity of isostructural cobalt(III)phenanthroline complexes. Journal of Chemical Sciences. 2015;127(4):649-661. https://doi.org/10. 1007/s12039-015-0817-y. 
Golubeva Yu. A., Smirnova K. S., Klyushova L. S. et al. Synthesis and crystal structure ... Голубева Ю. А., Смирнова К. С., Клюшова Л. С. и др. Синтез и кристаллическая структура ...

4. Al-Omair M. A. Biochemical activities and electronic spectra of different cobalt phenanthroline complexes. Arabian Journal of Chemistry. 2019;12(7):10611069. https://doi.org/10.1016/j.arabjc.2018.11.006.

5. Čongrádyová A., Jomová K., Kuckova L., Kožíšek J., Moncol' J., Valko M. Antimicrobial activity of copper(II) complexes. Journal of Microbiology, Biotechnology and Food Sciences. 2014;3(1):67-70.

6. Mahalakshmi R., Raman N. A Therapeutic journey of mixed ligand complexes containing 1,10-phenanthroline derivatives: A review. International Journal of Current Pharmaceutical Research. 2016;8(3):1-6.

7. Viganor L., Howe O., McCarron P., McCann M., Devereux M. The antibacterial activity of metal complexes containing 1,10-phenanthroline: Potential as alternative therapeutics in the era of antibiotic resistance. Current Topics in Medicinal Chemistry. 2016;17(11):1280-1302. https://doi.org/10.2174/1568026616666161003143333.

8. Galindo-Murillo R., García-Ramos J. C., RuizAzuara L., Cheatham T. E., Cortés-Guzmán F. Intercalation processes of copper complexes in DNA. Nucleic Acids Research. 2015;43(11):5364-5376. https://doi.org/10.1093/nar/gkv467.

9. Sigman D. S., Graham D. R., D'Aurora V., Stern A. M. Oxygen-dependent cleavage of DNA by the 1,10-phenanthroline.cuprous complex. Inhibition of Escherichia coli DNA polymerase I. Journal of Biological Chemistry. 1979;254(24):12269-12272.

10. Serment-Guerrero J., Bravo-Gomez M. E., Lara-Rivera E., Ruiz-Azuara L. Genotoxic assessment of the copper chelated compounds Casiopeinas: Clues about their mechanisms of action. Journal of Inorganic Biochemistry. 2017;166;68-75. https://doi.org/10.1016/ j.jinorgbio.2016.11.007.

11. Bravo-Gómez M. E., Dávila-Manzanilla S., Flood-Garibay J., Muciño-Hernández M. Á., Mendoza Á., García-Ramos J. C., et al. Secondary ligand effects on the cytotoxicity of several Casiopeina's group II compounds. Journal of the Mexican Chemical Society. 2012;56(1):85-92.

12. Tabti R., Tounsi N., Gaiddon C.,Bentouhami E., Désaubry L. Progress in copper complexes as anticancer agents. Medicinal Chemistry. 2017;7(5):875-879. https:// doi.org/10.4172/2161-0444.1000445.

13. Kletskov A. V., Bumagin N. A., Zubkov F. I., Grudinin D. G., Potkin V. I. Isothiazoles in the design and synthesis of biologically active substances and ligands for metal complexes. Synthesis. 2020;52(2):159-188. https: //doi.org/10.1055/s-0039-1690688.

14. Eremina J. A., Lider E. V., Sukhikh T. S., Klyushova L. S., Perepechaeva M. L., Sheven' D. G., et al. Water-soluble copper(II) complexes with 4,5-dichloro-isothiazole-3-carboxylic acid and heterocyclic
$\mathrm{N}$-donor ligands: Synthesis, crystal structures, cytotoxicity, and DNA binding study. Inorganica Chimica Acta. 2020;510. Article number 119778. https://doi. org/10.1016/j.ica.2020.119778.

15. Kaberdin R. V., Potkin V. I. Isothiazoles (1,2-thiazoles): synthesis, properties and applications. Russian Chemical Reviews. 2002;71(8):673-694.

16. De Oliveira Silva A., McQuade J., Szostak M. Recent Advances in the Synthesis and Reactivity of Isothiazoles. Advanced Synthesis and Catalysis. 2019;361(13):3050-3067. https://doi.org/10.1002/ adsc.201900072.

17. Perdew J. P., Burke K., Ernzerhof M. Generalized gradient approximation made simple. Physical Review Letters. 1996;77(18):3865-3868. https://doi.org/10.1103/PhysRevLett.77.3865.

18. Van Lenthe E., Baerends E. J. Optimized Slater-type basis sets for the elements 1-118. Journal of Computational Chemistry. 2003;24(9):1142-1156. https://doi.org/10.1002/jcc.10255.

19. Sheldrick G. M. SHELXT - Integrated space-group and crystal-structure determination. Acta Crystallographica, Section A: Foundations of Crystallography. 2015;A71(1):3-8. https://doi.org/10. 11 07/S2053273314026370.

20. Sheldrick G. M. Crystal structure refinement with SHELXL. Acta Crystallographica, Section C: Structural Chemistry. 2015;C71(1):3-8. https://doi. org/10.1107/S2053229614024218 3.

21. Dolomanov O. V., Bourhis L. J., Gildea R. J., Howard J. A. K., Puschmann H. OLEX2: A complete structure solution, refinement and analysis program. Journal of Applied Crystallography. 2009;42(2):339341. http://dx.doi.org/10.1107/S0021889808042726.

22. Eremina J. A., Lider E. V., Kuratieva N. V., Samsonenko D. G., Klyushova L. S., Sheven' D. G., et al. Synthesis and crystal structures of cytotoxic mixed-ligand copper(II) complexes with alkyl tetrazole and polypyridine derivatives. Inorganica Chimica Acta. 2021;516. Article number 120169. https://doi.org/10.1016/j.ica.2020.120169.

23. Pearson R. G. Absolute electronegativity and hardness: applications to organic chemistry. Journal of Organic Chemistry. 1989;54(6):14231430. https://doi.org/10.1021/jo00267a034.

24. Eremina J. A., Ermakova E. A., Smirnova K. S., Klyushova L. S., Berezin A. S., Sukhikh T. S., et al. $\mathrm{Cu}(\mathrm{II}), \mathrm{Co}(\mathrm{II}), \mathrm{Mn}$ (II) complexes with 5-phenyltetrazole and polypyridyl ligands: Synthesis, characterization and evaluation of the cytotoxicity and antimicrobial activity. Polyhedron. 2021;206. Article number 115352. https://doi.org/10.1016/j.poly.2021.115352.

\section{СпИсок Источников}

1. Bencini A., Lippolis V. 1,10-Phenanthroline: $A$ versatile building block for the construction of ligands for various purposes // Coordination Chemistry Reviews. 2010. Vol. 254, no. 17. P. 20962180. https://doi.org/10.1016/j.ccr.2010.04.008.

2. Krasnovskaya O., Naumov A., Guk D., Gorel-

kin P., Erofeev A., Beloglazkina E., et al. Copper coordination compounds as biologically active agents // International Journal of Molecular Sciences. 2020. Vol. 21, no. 11. P. 3965. https://doi.org/10.3390/ijms21113965.

3. Dey D., Roy A. B., Ranjani A., Gayathri L., 
Chandraleka S., Dhanasekaran D., et al. Synthesis and bio-catalytic activity of isostructural cobalt(III)phenanthroline complexes // Journal of Chemical Sciences. 2015. Vol. 127, no. 4. P. 649-661. https:// doi.org/10.1007/s12039-015-0817-y.

4. Al-Omair M. A. Biochemical activities and electronic spectra of different cobalt phenanthroline complexes // Arabian Journal of Chemistry. 2019. Vol. 12, no. 7. P. 1061-1069. https://doi.org/10.101 6/j.arabjc.2018.11.006.

5. Čongrádyová A., Jomová K., Kuckova L., Kožíšek J., Moncol' J., Valko M. Antimicrobial activity of copper(II) complexes // Journal of Microbiology, Biotechnology and Food Sciences. 2014. Vol. 3, special issue 1. P. 67-70.

6. Mahalakshmi R., Raman N. A Therapeutic journey of mixed ligand complexes containing 1,10phenanthroline derivatives: A review // International Journal of Current Pharmaceutical Research. 2016. Vol. 8, no. 3. P. 1-6.

7. Viganor L., Howe O., McCarron P., McCann M., Devereux $M$. The antibacterial activity of metal complexes containing 1,10-phenanthroline: Potential as alternative therapeutics in the era of antibiotic resistance // Current Topics in Medicinal Chemistry. 2016. Vol. 17, no. 11. P. 1280-1302. https://doi.org/ 10.2174/1568026616666161003143333.

8. Galindo-Murillo R., García-Ramos J. C., RuizAzuara L., Cheatham T. E., Cortés-Guzmán F. Intercalation processes of copper complexes in DNA // Nucleic Acids Research. 2015. Vol. 43, no. 11. P. 5364-5376. https://doi.org/10.1093/nar/gkv467.

9. Sigman D. S., Graham D. R., D'Aurora V., Stern A. M. Oxygen-dependent cleavage of DNA by the 1,10-phenanthroline.cuprous complex. Inhibition of Escherichia coli DNA polymerase I // Journal of Biological Chemistry. 1979. Vol. 254, no. 24. P. 12269-12272.

10. Serment-Guerrero J., Bravo-Gomez M. E., Lara-Rivera E., Ruiz-Azuara L. Genotoxic assessment of the copper chelated compounds Casiopeinas: Clues about their mechanisms of action // Journal of Inorganic Biochemistry. 2017. Vol. 166. P. 68-75. https://doi.org/10.1016/j.jinorgbio.2016.11.007.

11. Bravo-Gómez M. E., Dávila-Manzanilla S., Flood-Garibay J., Muciño-Hernández M. Á., Mendoza Á., García-Ramos J. C., et al. Secondary ligand effects on the cytotoxicity of several Casiopeína's group II compounds // Journal of the Mexican Chemical Society. 2012. Vol. 56, no. 1. P. 85-92.

12. Tabti R., Tounsi N., Gaiddon C.,Bentouhami E., Désaubry L. Progress in copper complexes as anticancer agents // Medicinal Chemistry. 2017. Vol. 7, no. 5. P. 875-879. https://doi.org/10.4172/21610444.1000445.

13. Kletskov A. V., Bumagin N. A., Zubkov F. I., Grudinin D. G., Potkin V. I. Isothiazoles in the design and synthesis of biologically active substances and ligands for metal complexes // Synthesis. 2020. Vol. 52, no 2. P. 159-188. https://doi.org/10.1055/s-00391690688.
14. Eremina J. A., Lider E. V., Sukhikh T. S., Klyushova L. S., Perepechaeva M. L., Sheven' D. G., et al. Water-soluble copper(II) complexes with 4,5-dichloro-isothiazole-3-carboxylic acid and heterocyclic $\mathrm{N}$-donor ligands: Synthesis, crystal structures, cytotoxicity, and DNA binding study // Inorganica Chimica Acta. 2020. Vol. 510. Article number 119778. https://doi.org/10.1016/j.ica.2020.119778.

15. Kaberdin R. V., Potkin V. I. Isothiazoles (1,2-thiazoles): synthesis, properties and applications // Russian Chemical Reviews. 2002. Vol. 71, no. 8. P. 673-694.

16. De Oliveira Silva A., McQuade J., Szostak M. Recent Advances in the Synthesis and Reactivity of Isothiazoles // Advanced Synthesis and Catalysis. 2019. Vol. 361, no. 13. P. 3050-3067. https://doi.org/ 10.1002/adsc.201900072.

17. Perdew J. P., Burke K., Ernzerhof M. Generalized gradient approximation made simple // Physical Review Letters. 1996. Vol. 77, no. 18. P. 38653868. https://doi.org/10.1103/PhysRevLett.77.3865.

18. Van Lenthe E., Baerends E. J. Optimized Slater-type basis sets for the elements 1-118 // Journal of Computational Chemistry. 2003. Vol. 24, no. 9. P. 1142-1156. https://doi.org/10.1002/jcc.10255.

19. Sheldrick G. M. SHELXT - Integrated space-group and crystal-structure determination // Acta Crystallographica, Section A: Foundations of Crystallography. 2015. Vol. A71, no. 1. P. 3-8. https://doi.org/10.1107/S2053273314026370.

20. Sheldrick G. M. Crystal structure refinement with SHELXL // Acta Crystallographica, Section C: Structural Chemistry. 2015, vol. C71, no. 1, pp. 3-8. https://doi.org/10.1107/S2053229614024218 3.

21. Dolomanov O. V., Bourhis L. J., Gildea R. J., Howard J. A. K., Puschmann H. OLEX2: A complete structure solution, refinement and analysis program // Journal of Applied Crystallography. 2009. Vol. 42, no 2. P. 339-341. http://dx.doi.org/10.1107/S002188 9808042726.

22. Eremina J. A., Lider E. V., Kuratieva N. V., Samsonenko D. G., Klyushova L. S., Sheven' D. G., et al. Synthesis and crystal structures of cytotoxic mixed-ligand copper(II) complexes with alkyl tetrazole and polypyridine derivatives // Inorganica Chimica Acta. 2021. Vol. 516. Article number 120169. https://doi.org/10.1016/j.ica.2020.120169.

23. Pearson R. G. Absolute electronegativity and hardness: applications to organic chemistry // Journal of Organic Chemistry. 1989. Vol. 54, no. 6. P. 1423-1430. https://doi.org/10.1021/jo00267a034.

24. Eremina J. A., Ermakova E. A., Smirnova K. S., Klyushova L. S., Berezin A. S., Sukhikh T. S., et al. $\mathrm{Cu}(\mathrm{II}), \mathrm{Co}(\mathrm{II}), \mathrm{Mn}(\mathrm{II})$ complexes with 5-phenyltetrazole and polypyridyl ligands: Synthesis, characterization and evaluation of the cytotoxicity and antimicrobial activity // Polyhedron. 2021. Vol. 206. Article number 115352. https://doi.org/10.1016/j.poly.2021.115352. 
Golubeva Yu. A., Smirnova K. S., Klyushova L. S. et al. Synthesis and crystal structure ...

Голубева Ю. А., Смирнова К. С., Клюшова Л. С. и др. Синтез и кристаллическая структура ...

INFORMATION ABOUT THE AUTHORS

Yuliya A. Golubeva,

Postgraduate Student,

Nikolaev Institute of Inorganic Chemistry

SB RAS,

3, Acad. Lavrentiev Ave., Novosibirsk, 630090,

Russian Federation,

julia1995@ngs.ru

https://orcid.org/0000-0002-5404-5357

Ksenia S. Smirnova,

Postgraduate Student,

Nikolaev Institute of Inorganic Chemistry

SB RAS

3, Acad. Lavrentiev Ave., Novosibirsk, 630090,

Russian Federation

smirnova ksenya96@mail.ru

https://orcid.org/0000-0002-6345-3467

Lubov' S. Klyushova,

Junior Researcher,

Institute of Molecular Biology and Biophysics,

Federal Research Center foe Fundamental

and Translational Medicine,

2/12, Timakov St., Novosibirsk, 630060,

Russian Federation,

klyushovals@mail.ru

https://orcid.org/0000-0003-4820-2536

Vladimir I. Potkin,

Dr. Sci. (Chemistry), Professor,

Institute of Physical Organic Chemistry

of the National Academy of Sciences

of Belarus,

13, Surganov St., Minsk, 220072 ,

Belarus,

potkin@ifoch.bas-net.by

https://orcid.org/0000-0001-7823-3208

\section{Elizaveta V. Lider,}

Cand. Sci. (Chemistry), Senior Scientist,

Nikolaev Institute of Inorganic Chemistry

SB RAS

3. Acad. Lavrentiev Ave., Novosibirsk, 630090,

Russian Federation,

lisalider@ngs.ru

https://orcid.org/0000-0003-4363-6829

\section{Contribution of the authors}

The authors contributed equally to this article.

\section{Conflict interests}

The authors declare no conflict of interests regarding the publication of this article.

The final manuscript has been read and approved by all the co-authors.

Information about the article

The article was submitted 19.10.2021. Approved after reviewing 15.11.2021.

Accepted for publication 30.11.2021.

\section{СВЕДЕНИЯ ОБ АВТОРАХ}

Ю. А. Голубева,

аспирант,

Институт неорганической химии

им. А. В. Николаева СО РАН,

630090, Новосибирск, пр-т Академика

Лаврентьева, 3 ,

Российская Федерация,

julia1995@ngs.ru

https://orcid.org/0000-0002-5404-5357

\section{К. С. Смирнова,}

аспирант,

Институт неорганической химии

им. А.В. Николаева СО РАН,

630090, Новосибирск,

пр-т Академика Лаврентьева, 3 ,

Российская Федерация,

smirnova_ksenya96@mail.ru

https://orcid.org/0000-0002-6345-3467

Л. С. Клюшова,

младший научный сотрудник,

Научно-исследовательский институт

молекулярной биологии и биофиизики -

структурное подразделение

Федерального исследовательского центра

фундаментальной и трансляционной

медицины,

630060, Новосибирск, ул. Тимакова, 2/12,

Российская Федерация,

klyushovals@mail.ru

https://orcid.org/0000-0003-4820-2536

В. И. Поткин,

д.Х.Н., профессор,

Институт фризико-органической химии

НАН Беларуси,

220072, Минск, ул. Сурганова, 13,

Беларусь,

potkin@ifoch.bas-net.by

https://orcid.org/0000-0001-7823-3208

\section{Е. В. Лидер,}

к.Х.Н., старший научный сотрудник,

Институт неорганической химии

им. А. В. Николаева СО РА,

630090, Новосибирск,

пр-т Академика Лаврентьева, 3 ,

Российская Федерация,

lisalider@ngs.ru

https://orcid.org/0000-0003-4363-6829

\section{Вклад авторое}

Все авторы сделали эквивалентный вклад в подготовку публикации.

\section{Конфоликт интересов}

Авторы заявляют об отсутствии конфрликта интересов.

Все авторы прочитали и одобрили окончательный вариант рукописи.

Информация о статье*

Поступила в редакцию 19.10.2021.

Одобрена после рецензирования 15.11.2021.

Принята к публикации 30.11.2021. 